\title{
Christian, Jewish and Muslim translations of the Bible and Koran in Byelorussia: 16th-19th centuries
}

\author{
BY \\ PAUL WEXLER
}

The period of the 16th and 17th centuries was an exciting time in the cultural history of the Byelorussian lands. The early 16th century saw the publication in Prague of Francis Skaryna's translation of the Bible into a Byelorussian recension of Church Slavonic $(1517-19)^{1}$ and the translation of the Old Testament into an even more colloquial 'Eastern Slavonic' by a Jewish translator at the close of the 15th century or early 16th century. ${ }^{2}$ The small Tatar community in the Grand Duchy of Lithuania also translated Muslim liturgical works into a form of colloquial Byelorussian. The earliest extant manuscripts probably date from the 17th century. The fact that minority groups chose to translate their religious literature into Byelorussian speaks eloquently of the high status of the Byelorussian language. A comparison of the three liturgical translations by Christian, Jewish and Muslim speakers of Byelorussian would undoubtedly contribute much to our understanding of (a) colloquial Byelorussian and (b) Byelorussian 'communal dialectology' in the Byelorussian lands in the 16th-17th centuries. The aim of the present article is to characterize briefly the language of the Jewish Bible translation, the Codex $\# 262,{ }^{3}$ with an eye to assessing its importance for Byelorussian (and Ukrainian) historical lexicography. Studies of the minority literary output have begun to appear in recent years and more studies are promised for the future. ${ }^{4}$ The analysis and publication of all the relevant documents should make a meaningful comparison feasible. This comparison should be a major desideratum for Byelorussian historical linguistics.

In many Jewish communities, the Bible and other Hebrew and Judaeo-Aramaic liturgical texts were translated into the colloquial language of the community. The language of translations differed radically from the spoken Jewish language by its extreme imitation of Hebrew word order, phraseology and derivational patterns and by the widespread rejection of outright loans from Hebrew and Judaeo-Aramaic (in opposition to most colloquial Jewish languages). The translation language was never inte.ded for spoken purposes, except perhaps for formal declamations. The only extant Judaeo-Eastern Slavonic 'calque' text, if we may use such a term, is the Codex \#262. The text, believed to date from the late 15th or early 16th century, has been described variously as 'Byelorussian', 'Ukrainian' and 'Russian' in language. ${ }^{5}$ The existence of a colloquial Eastern Slavonic calque text is circumstantial evidence for the existence of a colloquial Judaeo-Eastern Slavonic lan- 
guage in the 15th-16th centuries, since there appears to be no Jewish community that uses a calque language in the absence of a unique colloquial Jewish language.

The Codex might have been intended for Jews ignorant of Hebrew, but the fact that the translation is preserved in a Cyrillic rather than Hebrew script, the traditional medium of Jewish calque translations, suggests that this particular manuscript may have been intended for a Christian readership. ${ }^{6}$ If this manuscript were copied down by a nonJew, then the spelling norms are irrelevant for us. Codex \#262 has been discussed in the scholarly literature for about a century, yet despite frequent citations, especially in current Byelorussian lexicographical studies, the full text, together with a linguistic analysis, has not yet been published. ${ }^{7}$ Scholars have long recognized that the importance of the Codex lies in the fact that it is one of the first texts from the Byelorussian lands containing large sections which are relatively free of Church Slavonic influence. However, all the Soviet historical lexicographical studies totally ignore the calque origin of the text. For example, the Histaryčny stounik biełaruskaj movy (ed. A.M. Bułyka, 1982-) lists Byelorussian lexical innovations and Hebrew-Judaeo-Aramaic loans found uniquely in the Codex with no characterization of their origin; the reader hardly can suspect that these items do not reflect general Byelorussian literary norms of the 15th-16th centuries. The only merit of the dictionary is to assemble 'Byelorussianisms' that are not attested in any other document. Without consulting the Hebrew text, it is not surprising that the dictionary is replete with errors of interpretation. For example, aptéku acc.sg. (Job 41.23) is translated as 'medicine', though the term actually translates Hebrew merqāhäh 'vessel for boiling spices'. The Jewish translators used aptěka in this new meaning, since merqāhāh , derived from the root $r-q-h$ 'concoct, spice, mix' also expresses the notion 'pharmacy' (as in Hebrew bèt mirqahat, literally 'house of spices'). Skaryna's contemporaneous translation of 1517 renders Hebrew merqāhāa as jakovy ehda masti kipęt'.

The Codex \#262 shows clearly that the written Byelorussian language of minority communities may not be necessarily closer to colloquial norms (i.e., of the minority community) than the Byelorussian recension of Church Slavonic; however, Byelorussian liturgical translations done by Jews and Muslims may prove to retain numerous colloquial features unattested in the written Byelorussian of Christians. Certainly, Nieściarovic errs in assuming that minority texts are by definition closer to the colloquial language than Christian Byelorussian texts. ${ }^{8}$ In comparing the three literary traditions, it would be wise not to extrapolate mechanically from one communal dialect to another.

Students of the Codex have regarded the non-Eastern Slavonic components in the text as Church Slavonicisms, e.g. nošt' ( $\sim$ noč) 'night', zlato ( zoloto) 'gold'. But the presence of numerous elements from the traditional medium of Bible translations in the Eastern Slavonic lands is puzzling if a Jewish authorship (and readership) were intended. The presence of a South Slavonic component in the Codex might be 
explained in two ways: (a) the text was produced by Jews for the exclusive use of a Christian, or Judaicizing readership; (b) the use of a South Slavonic component would be natural among Jews whose native language was South Slavonic or whose calque language tradition had originally developed in a South Slavonic milieu. In the second case, the South Slavonic components of the Codex should be defined as '(Judaeo-) Bulgarian' rather than 'Church Slavonic'. Altbauer has observed that in the Book of Daniel, portions which were originally written in JudaeoAramaic appear in 'Church Slavonic' while in the translation of Hebrew portions of the Book of Daniel colloquial Byelorussian elements predominate. ${ }^{9}$ The distribution of Church Slavonic and Eastern Slavonic in the Codex thus stands in opposition to the diglossic situation prevailing in the Eastern Slavonic lands at this time - namely, (colloquial) Aramaic: (literary) Church Slavonic:: (literary) Hebrew: (colloquial) Eastern Slavonic. At present, I have no evidence of a Jewish calque language from the South Slavonic lands, and I cannot point to any unique South Slavonic element in the Codex.

The Codex often follows Hebrew syntactic norms, even at the expense of violating Slavonic grammatical norms. Thus, because Byelorussian and Ukrainian lack lexical means of expressing definiteness, the Hebrew definite article is rendered in the Codex by a demonstrative pronoun, e.g. Hebrew ha-jeled 'the boy' (Ruth 4.16) > onoe ditę; Hebrew ha-na'aräh 'the girl' (Esther 2.13) > tae molodica. ${ }^{10}$ Another example of Hebrew syntactic interference is the treatment of the Biblical Hebrew construction known as the 'tautologous infinitive', which consists either of the infinitive followed by a finite verb (to express emphasis) or of a finite verb followed by the infinitive (to express duration). The Hebrew tautologous infinitive is translated in the Codex by a participle and finite verb; such a construction is not found in Skaryna's translation. Examples (with the finite verb in final position) are Hebrew hugged huggad 'it was told' (Ruth 2.11) > povèda povědano (vs. Skaryna povedeli sut' mnĕ); Hebrew hahareš taharīš̀ 'you will be silent' (Esther 4.14) > molčači zmolčiš (vs. Skaryna ty. . . budeš molčati). The Slavonic languages have a discontinuous construction involving an infinitive and finite verb, which is first found in the 16th century Polish Biblia Zofia. ${ }^{11}$

There are numerous examples in the Codex where Hebrew word order has been grafted onto the Eastern Slavonic text. For instance, Hebrew bèn-ī- $\bar{u}$-vèn-ex 'between you and me' (Ruth 1.17) (literally 'between-me and-between-you') > meži mnoju i meži toboju (vs. Skaryna [smert] mene rozlučit' ot tebe). The Codex often imitates Hebrew derivational patterns by matching all forms of a Hebrew root with a single Slavonic stem, e.g. Hebrew šaharüt 'youth' (Ecclesiastes 11.10) > černost' (< černyj 'black') since Hebrew forms of the same root $s-h-r$, e.g. šăhōr, šahar denote 'black' and 'dawn, darkness' respectively (vs. Skaryna mladosti). All forms of Hebrew $g-'-l$ 'redeem' in Ruth 4.3-7 are translated by a common Slavonic stem - Hebrew ha-gō'el 'the redeemer', li-g'ōl 'to redeem', gā'al 'he redeemed' and goülätī 'my redemption' are translated as okupitel', okupiti, okupi, okupen'e; Skary- 
na's translation uses three separate roots: bližnemu, vladěti, kuplju. ${ }^{12}$ Hebrew derived verbs are often paired with Slavonic prefixed verbs. Examples are Hebrew šilţ-ōn 'rule' (Ecclesiastes 8.4), sālìţ 'ruler' (Ecclesiastes 8.8), šălāt 'he ruled' (Ecclesiastes 8.9) > vladar', ${ }^{13}$ voloditel, ${ }^{14}$ vlodërev" (plural) and voloděl" respectively; in Skaryna, the first three words are translated by separate roots: kreposti, moci, vladeet' respectively. Occasionally, the principle of root matching obliges the translator to create innovative (often prefixed) verbs, e.g. Hebrew jэ-gabber 'he encouraged, strengthened' (Ecclesiastes 10.10) (< gāvar 'he overcame') $>v$ 'sxorobręt' (vs. Skaryna $z$ velikoju praceju vyostreno budet).

The compulsion to match each Slavonic root with a single Hebrew counterpart may also account for the abolition of Slavonic morphophonemic alternations. For instance, blisk 'brilliance, glitter' (Esther 1.6), unattested in Old Byelorussian texts (for expected Old Eastern Slavonic blèsk" - see modern Byelorussian blask - a Polonism), may have been created from the verb blistati 'to glitter', in order to match the Hebrew root $l-h-v$ which denotes both the verb and the noun (e.g. lāhav 'it glittered, burned': lahav 'glitter, flame'). Alternatively, Ukrainian blysk may be the source of this term; see also Old Russian blisku (locative, 14 th century). ${ }^{15}$

The Codex has a number of Slavonic words either unknown altogether in Byelorussian or with meanings unattested elsewhere. Invariably, these words have cognates in the West Slavonic languages. Such terms are either Judaeo-Eastern Slavonic innovations prompted by the desire to imitate the Hebrew text, or borrowings from colloquial Judaeo-Western Slavonic. A specifically Judaeo-Western Slavonic source could be attractive in the absence of a cognate in non-Jewish Byelorussian sources or if the form and/or meaning of the West Slavonicism in the Codex differs from that of the cognate in Byelorussian or the West Slavonic source languages. The possibility that the Codex might assist us in recovering Judaeo-Western Slavonic elements should be systematically explored. Consider holubice, used in the Codex for 'dove', corresponding to Hebrew jōnäti (literally 'my dove': Song of Songs 6.9) Czech holubice 'little pigeon'; milostnik", a translation of Hebrew dōdī 'my lover' (Song of Songs 2.9); Skaryna has milyi moi. Early 19th-century Tatar Byelorussian also has the term in this meaning, ${ }^{16}$ but otherwise the form with -nik is attested with this meaning only in Western Slavonic languages, e.g. Polish mitośnik 'lover, paramour, admirer; (archaic) friend, amateur'; Czech milostník 'lover, paramour; favourite'; Eastern Slavonic languages use the word in a different sense, see e.g. Old Byelorussian milostnik" 'favourite, amateur' (1519), ${ }^{17}$ Byelorussian miłaśnik 'benefactor, well-wisher' (19th century); ${ }^{18}$ Russian milostnik 'pet, favourite'. ${ }^{19}$ It was also noted by Vladimirov, the first serious student of the language of Skaryna's Bible translations, that there was a Czech linguistic imprint in the translations. ${ }^{20}$

It should be apparent from the brief remarks above that the Codex \#262 can help us to assess the colloquial Byelorussian component in 
Skaryna's translation. The fact that the Codex, the Tatar translations from Arabic and Turkic and Skaryna's Bible all, each in its own way, reveal a Western Slavonic linguistic impact calls for a separate study of the differential impact of Western Slavonic on the three religious communities in Byelorussia. In addition to recovering colloquial Byelorussian norms, a systematic comparison of Christian, Jewish and Muslim documents might enable us to uncover reciprocal influences among the three groups. Finally, the Jewish and Muslim documents may assist in uncovering some features of colloquial Jewish and Muslim Byelorussian speech. The impact of Arabic and Turkic on the Byelorussian norms of the Tatar community constitutes a separate study.

It is perhaps fitting that these preliminary remarks were first read at a conference at the Francis Skaryna Library in London. After all, this is the only library in the West with original and photostatic Byelorussian Tatar materials as well as photostats of the complete text of the Skaryna Bible translation and Codex \#262. The student of Byelorussian and Eastern Slavonic historical lexicography would find a visit to North Finchley to be highly rewarding.

\section{NOTES}

1. F. Skaryna, Bivlija ruska, Prague, 1517-19.

2. The Jewish community in Byelorussia in the early 16th century comprised an autochthonous Eastern Slavonic-speaking group (whose historical origins are barely understood) and an Ashkenazic community of Yiddish-speaking Jews who had begun to migrate to the Byelorussian lands in the 1400 s from the West. On the languages of the Slavonic-speaking Jews, see P. Wexler, Explorations in Judeo-Slavic Linguistics, Leiden, 1986.

3. Codex \#262 [Daniel, Ecclesiastes, Esther, Job, Lamentations, Proverbs, Ruth, Song of Songs] (late 15th-early 16th century). Ms. folios 12a-134b, Central Library, Lithuanian Academy of Sciences, Vilnius.

4. See S. Akiner, 'The vocabulary of a Byelorussian Tatar K'it'ab in the British Museum', The Journal of Byelorussian Studies, III, 1, 1973, pp.55-84: id., 'The religious vocabulary of the British Library Tatar-Byelorussian Kitab', Ph.D thesis, University of London, 1980; M. Altbauer, 'O pewnej funkcji nieodmiennego imiesłowu czynnego czasu teraźnicjszego w Polszczyznie', in Studia linguistica in honorem Thaddei Lehr-Splawinski, ed. T. Milewski et al., Cracow, 1963, pp.333-37; id., 'Dublety imion biblijnych w polszczyznie', Onomastica, 10, 1965, pp.196-203; id., 'O technice przekładowej Szymona Budnego', in Studia jezykoznawzce poswięcone Profesorowi Doktorowi Stanislawowi Rospondowi. Wrocław, 1966, pp.85-96; id., 'O kryteriach ustalania pierwowzoru tłumaczeń biblijnych (na podstawie wschodniosłowiańskego thumaczenia księgi Ruty), Slavia, 36(4), 1967, pp.590-600; id.,'Ze studiow nad wschodniosłowiańskimi przekładami Biblii (o dwóch przekładach biblijnego akrostychu o zacnej niewiecie)', Studia $z$ filologiej polskiej i stowianskiej, 7, 1967, pp.179-90; id., Some methodological problems in research of the East-Slavic Bible translations (Vilnius Codex \#262), Jerusalem, 1968; id., 'Staroczeskie gduc//staropolskie gydøcz// szedl. (O słowiańskiej replice biblijnego bō'axā), in Symbolae philologicae in honorem Vitoldi Taszycki, Wrocław-Warsaw-Cracow, pp.10-15; id., 'A previously unnoticed Slavic and Baltic Dativus Auctoris', in Donum Balticum. 
To Professor Christian S. Stang on the occasion of his seventieth birthday 15 March 1970, ed. V. Rūke-Dravina, 1-5, Stockholm, 1970; id., 'Studies in the vocabulary of the Byelorussian translations of the Bible', The Journal of Byelorussian Studies, II, 4, 1972, pp.359-68; id., The Five Biblical Scrolls in an East Slavic Translation. (A Chapter in the History of Translation Technique), ms (to be published by the Israel Academy of Sciences, Jerusalem); P. Wexler, 'Jewish, Tatar and Karaite communal dialects and their importance for Byelorussian historical linguistics', The Journal of Byelorussian Studies, III, 1, 1973, pp.41-54.

While most of the extant Byelorussian Tatar manuscripts and the Codex \#262 are housed at the Lithuanian Academy of Sciences in Vilnius and the Vilnius University library, Soviet scholars have generally shown little enthusiasm for publishing detailed analyses of these documents. For two recent Soviet discussions of Byelorussian Tatar texts, see V. Nieściarovič, 'Frazieałahizmy (fraziemy) biełaruskaha tekstu, napisanaha arabskim pismom', in Bietaruskaja frazieatohija, leksikalohija. Zbornik artykułaŭ, ed. F. Jankoŭski, Minsk, 1980, pp.32-41; id, 'Pra niekatoryja moŭnyja asablivaści biełaruskich tekstaŭ arabskim piśmom XVIII-XIX stst.' in Stova, frazieałahizm, słovazłučeńnie. Zbornik artykulaū, ed. F. Jankoŭski, Minsk, 1984, pp. 92-97.

5. V.N. Peretc ('Dokumenty Biblejskoj Komissii. [Ed. K.I. Logacev]', Bogoslovskie trudy, 14, Moscow, pp.206-07) regards the language of the Codex as Ukrainian; A.A. Arxipov (Drevnerusskaja kniga proroka Daniila $v$ perevode $s$ drevneevrejskogo. $K$ istorii gebraizmov $v$ drevnerusskom knižnom jazyke, 1-3, Moscow, 1982, part 1, p.11) defines the language as 'Southwest Russian', and Byelorussian scholars regard the text as 'Byelorussian' (see Histaryčny słoŭnik biełaruskaj movy, ed. A.M. Bułyka, Minsk, 1982-). Distinctive Byelorussian features include akańnie, $h$ for Common Slavonic ${ }^{*} g$, orthographic confusion of $u$ and $v$. On the problems of distinguishing Byelorussian from Ukrainian texts in this period, see G.Y. Shevelov, 'Byelorussian versus Ukrainian: delimitation of texts before A.D. 1569', The Journal of Byelorussian Studies, III, 2, 1974, pp.145-56 (with rich bibliography). The label 'Kiev-Palessian' or 'Połack-Rjazan" may be more accurate for the language of the Codex than the anachronistic use of the term 'Byelorussian' or 'Ukrainian' (see discussion in Shevelov [Šerech], Problems in the Formation of Belorussian, New York, 1953; and Wexler, A Historical Phonology of the Belorussian Language, Heidelberg, 1977, pp. 52-61). It is to be hoped that the Altbauer ms (see fn.4) will clarify the dialect make-up of the Codex.

6. V. Łastoŭski (Historyja biełaruskaj (kryŭskaj) knihi. Sproba pajaśnicielnaj knihopisi ad kanca $X$ da pacatku XIX stahodździa, Kaunas, 1926, p.242) is of the opinion that Byelorussian translations made directly from Hebrew were intended for Judaizing sects. E.F. Karskij (Belorusy. 3. Očerki slovesnosti belorusskogo plemeni. 2. Staraja zapadnorusskaja pis'mennost', Prague, 1921, p.19) and Ja. Stankievic (Dola movy bietaruskaje (jaje vonkasnjaja historyja) u roznija peryjady historyi Bietarusi, New York [offprint from Vieda], 1954, p.5) believe the translation was used in the synagogue, while A.V. Florovskij ('Cešskaja Biblija v istorii russkoj kul'tury i pis'mennosti', Sbornik filologický, 12, 1940-46, pp.160-61) and D. Ciževskij ('Altrussische wissenschaftliche Literatur und die Judaisierenden', Die Welt der Slaven, 11 , no. 4,1966, p. 355) stipulate that it was meant for Jews ignorant of Hebrew. The fact that Hebrew anthroponyms appear both in Hebrew and 
traditional Church Slavonic forms suggests that the translator and the scribe were not the same person (see Arxipov, Drevnerusskaja kniga proroka Daniila. ., part 1, p.13; id., Iz istorii gebraizmov $v$ russkom knižnom jazyke $X V-X V I$ vekov. Avtoreferat. Dissertation for the degree of Kandidat filologičeskix nauk, M.V. Lomonosov State University, Moscow, 1982, p.16). Note also Karskij's remark that while the work had been translated directly from Hebrew, it was later adjusted to the Church Slavonic translation (Zapadnorusskie perevody psaltyri $v$ XV-XVII vekax, Warsaw, 1896, p.27). On the possibility that Symon Budny patterned his Polish Bible translation (the Biblia nieświeska 1572) on the Hebrew Bible and consulted Jewish informants, see Altbauer, 'O technice przekładowej Szymona Budnego', p.95 and $\mathrm{fn} .14$.

7. The only scholars in recent years to study the Codex systematically are Altbauer (see works cited in fn.4) and Arxipov (Drevnerusskaja kniga proroka Daniila. . .; Iz istorii gebraizmov. ..). Parts of the translation (Ruth, Daniel) have been reprinted or photostatted and the text as a whole has been described in passing by P.V. Vladimirov, Doktor Francisk Skorina. Ego perevody, pečatnye izdanija i jazyk, St Petersburg, 1888, pp.239-41, 337-38, 32444; Karskij, $K$ istorii zvukov i form belorusskoj reci, Warsaw, 1893, pp.88116; id., Zapadnorusskie perevody psaltyri $v$ XV-XVII vekax, pp.26-34; id., Belorusy. 3. pp.18-21; id., Belorusy. Jazyk belorusskogo naroda. 1, Moscow, 1955, pp.56-73; I.E. Evseev, 'Kniga proroka Daniila v perevode židovstvujušcix po rukopisi XVI v.', in I.E. Evseev et al., $O$ eresi židovstvujuščix. Novye materialy, Moscow, 1902, pp.127-64; M.N. Speranskij, Iz istorii otrecennyx knig. IV. Aristotelevy vrata ili Tajnaja tajnyx, St Petersburg, 1908, pp.99-100, fn.3, 114ff.; Łastoŭski, op. cit., pp.241-43; Florovskij, op. cit., pp.159-60; A.I. Žuraŭski, 'Da pytańnia ab roli carkoŭnasłavianskaj movy ŭ raźvićci biełaruskaj litaraturnaj movy XVI st.', in Materyjaty da IV mižnarodnaha zjezda stavistaŭ, Minsk, 1958, pp.57-58; id., Historyja bietaruskaj litaraturnaj movy. 1, Minsk, 1967, pp.159-60, 165-66; Chrestamatyja pa historyi bietaruskaj movy. I, ed. U.V. Anicenka et al., Minsk, 1961, pp.119-25; Histaryčnaja leksikałohija biełaruskaj movy, ed. Ja. Bachańkoŭ et al., Minsk, 1970, passim; A.M. Bułyka, Daūnyja zapazyčańni biełaruskaj movy, Minsk, 1972, passim; Histaryčny stoünik bielaruskaj movy, passim; A.A. Alekseev, 'Pesn' pesnej po russkomu spisku XVI v. v perevode s drevneevrejskogo originala', Palestinskij sbornik, 27 (90), 1981. Altbauer (ms) is presently preparing the publication of the five scrolls.

8. Nieściarovič, 'Pra niekatoryja moŭnyja asablivaści. . ' p.92.

9. Altbauer, Some methodological problems. .., p.2. See also Arxipov, Drevnerusskaja kniga proroka Daniila. .., part 1, 23ff.; id., Iz istorii gebraizmov. .., pp.18-19.

10. See also discussion in Arxipov, Drevnerusskaja kniga proroka Daniila..., part 3, 12ff.; id., Iz istorii gebraizmov..., p.23. The use of the demonstrative pronoun as a definite article in 16th-century Polish Bible translations is cited by Altbauer ('O technice przekładowej Szymona Budnego', p.90). In the Hebrew examples - denotes a morpheme boundary, except in the citation of roots where - separates the consonants in the discontinuous root morpheme.

11. Altbauer, 'O pewnej funkcji nieodmiennego imiesłowu. ..'; id., 'O technice przekładowej Szymona Budnego'; id., 'Staroczeskie gduc // staropolskie gydøcz // szedl. .', p.14. Stankievič's Byelorussian translation of the Bible (Sviataja Biblja, New York, 1973) contains examples of participle + finite 
verbs, e.g. Hebrew $s \bar{a}^{c} \bar{o} l s \bar{a}^{c} a l$ 'he indeed asked' (Genesis 43.7) , Byelorussian pytajučy, raspytavaū. For additional examples from the Codex, see Arxipov, Drevnerusskaja kniga proroka Daniila. ., part 3, p.5.

12. See also Altbauer ('O technice przekładowej Szymona Budnego', p.91), who adds the Polish translation equivalents from Budny (1572): powinowaty, odkup(ić), bliskość. For further examples, see Arxipov, Drevnerusskaja kniga proroka Daniila. .., part 2, p.4; id., Iz istorii gebraizmov. ., p.22.

13. This term is not attested in Skaryna's translation, nor in Church Slavonic texts. Vladar' is found in Old Ukrainian (15th century), where it is a loan from Old Polish wtodarz wtadarz 'superintendent of the king's property'; a cognate is also found in Old Czech (see Slovnik staroukrajins'koji movy, 1-2, ed. D.H. Hryncyšyn et al., Kiev, 1977-78). The Judaeo-Eastern Slavonic calque form might be derived from Old Czech vladar.

14. The surface cognate in Skaryna's text is vladetel' 'ruler; owner'.

15. See I.I. Sreznevskij (Materialy dlja slovarja drevnerusskogo jazyka po pis'mennym pamjatnikam [facsimile reprint of 1893-1903 edn.], Moscow, 1958), who fails to define the source of this form in his index of sources. For the various reflexes of Old Eastern Slavonic blesk ${ }^{\sim}$ in Ukrainian, see Atlas ukrajins'koji movy, 1. Polissja, Serednja Naddniprjanščyna i sumežni zemli, ed. I.H. Matvijas et al., Kiev, 1984, map \#6.

16. See Akiner, 'The religious vocabulary of the British Library Tatar-Byelorussian Kitab', p.170. The term is used to translate Arabic habib (allah) 'beloved (of Allah)', an epithet for Muhammad. A comparison of Jewish and Muslim Byelorussian isoglosses would be instructive; for bibliography of Muslim texts, see Wexler, A Historical Phonology of the Belorussian Language.

17. Skaryna (see Slounik movy Skaryny, 1-2, ed. U.V. Anicenka, Minsk, 1977-84).

18. A.B. McMillin (The Vocabulary of the Byelorussian Literary Language in the Nineteenth Century, London, 1973, p.222) cites the term from DuninMarcinkievic 1846. The term is not listed in Ttumačalny stoŭnik bietaruskaj movy, ed. K.K. Atraxovič et al., Minsk, 1977-84. Old Ukrainian mylostynnyk is glossed as 'almsgiver' (Slovnik staroukrajins'koji movy).

19. V.I. Dal', Tolkovyj slovar' živogo velikorusskogo jazyka [facsimile reprint of 1880-82 edn.], Moscow, 1956; Slovar' russkogo jazyka XI-XVII vv., ed. S.G. Barxudarov et al., Moscow, 1975ff.

20. See the remarks of Vladimirov (op.cit.) cited by U. Piceta, 'Scoriniana (1776-1926)', in Catyroxsotlećcie bielaruskaha druku 1525-1925, Minsk, 1926, pp.294ff. A.I. Sobolevskij (Review of Vladimirov in Žurnal Ministerstva Narodnogo Prosvešcenija, part 259, 10, 1888, pp.321-22) disputed the idea of a Czech prototype for Skaryna's Bible translation. 